Eskişehir Osmangazi Üniversitesi iiBF Dergisi

Nisan 2020, C. 15, S. 1, 371 - 388.

Başvuru : : 10.11.2018

Kabul : :26.01.2020

\title{
Mutluluk ve Uluslararası Göç: Genel Bir Bakış ${ }^{1}$
}

\begin{abstract}
Mutluluk ve Uluslararası Göç: Genel bir Bakış
Öz

Son yıllarda mutluluk ekonomisi adı altında yapılan çalışmalarda bireylerin yaşam memnuniyeti üzerinde yalnızca mutlak gelir gibi nesnel kriterlerin etkisinin olmadığı, Neo-klasik kuramın ihmal ettiği bireyin yaş, cinsiyet, istihdam durumu, eğitim, medeni durum gibi sosyo-demografik özelliklerinin yanı sıra nispi gelir, kurumsal faktörler, etnik kimlik, ayrımcılık vb. pek çok faktörün de etkili olduğu tespit edilmiştir. Bireyin göç kararının altında birçok etken yatmaktadır. Bunlardan en önemlilerinden birisi göç sonrası elde etmeyi umdukları ekonomik iyileşmedir. Ancak bireylerin gelirlerinde göç sonrası mutlak anlamda bir artış yaşansa bile yaşam memnuniyetleri beklenilenin aksine azalabilir. Göç sonrası bireyler kendilerini varış ülkesindeki veya geride bıraktığı ülkedeki bireylerle ekonomik ve sosyal açıdan kıyaslama eğilimindedirler. Yapılan çalışmalarda göç eden bireylerin mutluluğu üzerinde mutlak gelir yerine nispi gelirin daha belirleyici olduğu tespit edilmiştir. Bu çalışma mutluluk-göç ilişkisi üzerine yapılan bir literatür araştırmasıdır.
\end{abstract}

Anahtar Kelimeler: Mutluluk, Yaşam Memnuniyeti, Nispi Gelir, Göç, Adaptasyon
Happiness and International Migration: An Overview

Abstract

In recent happiness economy studies, it has been found that objective criteria such as absolute income is not the only effect on the life satisfaction of individuals. Sociodemographic characteristics such as age, gender, employment status, education, marital status neglected by neo-classical theory and many other factors like relative income, institutional factors, ethnic identity, discrimination etc. influence life satisfaction. There are many factors which effect immigration decision of individual. One of the most important ones is the economic improvement that they hope to obtain after migration. However, even if there is an absolute increase in the income of the individuals after the migration, their life satisfaction may decrease on the contrary to expectations. Post-migration individuals tend to compare themselves economically and socially with individuals in the country of destination or the country they left behind. Previous studies reveal that relative income is decisive on happiness of immigrants instead of absolute income. This study is a literature review regarding happiness-migration relation.

Keywords: Happiness, Life Satisfaction, Relative Income, Immigration, Adaptation

\section{Giriş}

Neoklasik kuram insanı toplumsal bir varlık olarak görmemekte, insanın içinde doğup büyüdüğü toplum ve o toplumu oluşturan sınıf, dini cemaat, grup, sendika, değer yargıSı, politik görüş gibi kavramlardan ve de cinsiyet, yaş, inanç, medeni durum gibi sosyo-demografik özelliklerden ayrı tutmaktadır. Neoklasik kuramın rasyonel bireyi, yalnızca kendi çıkarlarını gözeten, bencil, toplum ve kişisel özelliklerinden soyutlanmış bir bireydir. Bu nedenle kurama göre, bireyin yaşam memnuniyeti "mutlak gelir" gibi objektif iktisadi parametreler ile kolayca ölçülebilmektedir. Bireyi ve bireyin içinde yaşadığı toplumu oluşturan ve etkileyen diğer tüm faktörler dışlanmaktadır (Erim, 2011: 119-120).

Son yıllarda mutluluk ekonomisi adı altında yapılan çalışmalarda bireylerin yaşam memnuniyeti üzerinde yalnızca nesnel kriterlerin etkili olmadığı, neoklasik kuramın görmezden

\footnotetext{
${ }^{1}$ Bu çalışma Marmara Üniversitesi İktisadi ve İdari Bilimler Fakültesi Sosyal Bilimler Enstitüsü İktisat Teorisi Anabilim Dalı’nda Prof. Dr. Suat Oktar danışmanlığında Songül Gül tarafından “Mutluluk Ekonomisi ve Göç Üzerine Bir Uygulama” ismiyle tamamlanarak 04.01.2017 tarihinde savunulan doktora tezinden türetilmiştir.

2 Dr. Öğr. Üyesi. Ağrı İbrahim Çeçen Üniversitesi iỉBF, İktisat Bölümü. sgul@agri.edu.tr, Yazar ORCID bilgisi: https://orcid.org/0000-0002-0310-4310
} 
geldiği yaş, cinsiyet, ırk, istihdam, eğitim, medeni durum gibi sosyo demografik özelliklerinin yanı sıra kurumsal faktörler, etnik kimlik, ayrımcılık, dışlanma vb. pek çok faktörün de etkili olduğu tespit edilmiştir (Easterlin, 1974; Clark vd., 2006; Helliwell, 2003; Lelkes, 2006).

Mutluluk çalışmalarının ekonomistlerce incelenmesinin pek çok nedeni olmakla birlikte bunlardan en önemlisi, bireylerin refah ve mutluluğunun doğrudan ekonomik durumları ile ilişkilendirilmesidir. Ekonomistlere göre bireylerin iyi oluş halini gösteren nesnel ölçütler mevcuttur ve toplumun yaşam kalitesi de bu nesnel ölçütler ile kolayca anlaşılmaktadır (Gökdemir Dumludağ, 2011: 51).

Mutluluk-göç literatüründe yapılan çalışmalarda, bir başka ülkeye göç eden bireylerin sadece mutlak gelirlerini arttırma yolu ile mutlu olup olmadıkları ve buna ilaveten göç esnasında ve sonrasında yaşanan ekonomik, sosyal ve psikolojik gelişmelerin de bireylerin yaşam memnuniyeti üzerindeki etkisi araştırılmaktadır (Stillman, S. vd., 2015; Dittmann, J. ve Goebel, J., 2010; Bartram 2013b vb.). Bu makale mutluluk-göç alanında yapılan çalışmalarla ilgili bir literatür araştırması olup Türkçe literatüre bir katkı sağlayacağı düşünülmektedir.

Mutluluk konusuna son yıllarda artan ilgi dolayısıyla bu alanda yapılan çalışmaların sayısı hızla artmakta ve buna paralel olarak günümüzde mutluluğun belirleyicilerini tespit etmek amacı ile birçok bilim dalında çalışmalar yapılmaktadır.

\section{Grafik 1: Bilimsel Alanda Beş Yıllık Periyotlar Boyunca Yayımlanan Makale Sayısı}

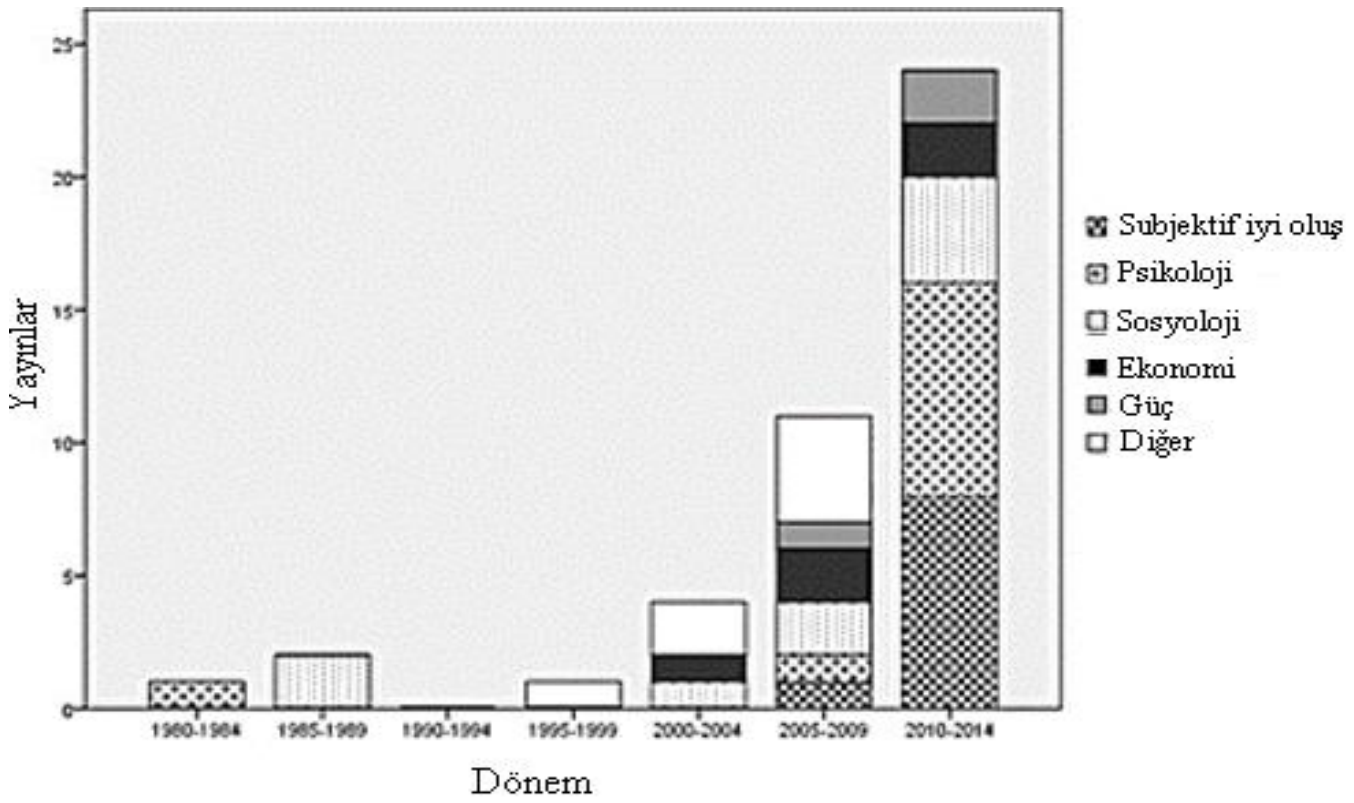

Kaynak: Hendriks, 2015: 343-369.

Grafik 1'de görüldüğü üzere ilk zamanlarda sosyoloji ve psikoloji alanında yapılmaya başlanan mutluluk çalışmaları, 2000'li yıllarda diğer bilim dallarında da yapılmaya başlanmış ve bu alanda yapılan çalışmalarda önemli oranda bir artış yaşanmıştır. 


\section{Kuramsal ve Kavramsal Çerçeve}

Savaş, doğal afet vb. nedenler dışında bireyler genellikle refahlarını arttırmak ve daha iyi yaşam standartlarına kavuşmak amacı ile göç etmektedirler. Asıl amacı göç yolu ile mutluluğunu arttırmak olan birey, göçü bu yolda bir araç olarak kullanmaktadır. Bu nedenle göç alanında yapılan mutluluk çalışmaları, aynı zamanda göçmenlerin bu amaçlarına ulaşıp ulaşmadıklarının da bir göstergesi olabilmektedir. Mutluluk-göç araştırmalarında göç sonucu göçmenlerin, hangi şartlar altında ve ne derece mutlu oldukları, hangi ülkelere göç etme eğiliminde oldukları, zengin ülkelere göç etmenin daha fazla mutluluk getirip getirmediği ve göç sonrası gelir artışının mutluluğu arttırmada tek başına yeterli olup olmadığı gibi vb. sorulara yanıt aranmaktadır.

Neoklasik ekonomi teorisinin mevcut teorik çerçevesine göre, göç literatüründe birey göç kararı verdiği zaman yeterli bilgiye sahiptir ve gerçekçi olmayan umutları yoktur. Teori, parasal ve parasal olmayan maliyet ve kazançlar göz önüne alındığında bireylerin göç kararı alırken gelecekteki maliyet ve kazançları tam olarak hesaplayıp rasyonel bir seçim yaptıklarını söylemektedir (Melzer vd., 2012: 2-9). Fakat gerçek hayatta göçmenler yeterli bilgiye sahip olmayabilirler ve gerçekçi olmayan beklentilerle ya da gelecekte karşılaşacağı maliyetlerle ilgili yanlış hesaplamalar yapıp göç kararı almış olabilirler. Bireyin göç sonrası karşılaşacağı bu maddi ve psiko-sosyal maliyetlerin boyutu göçmenin öngördüğü doğrultuda çıkmadığı takdirde, birey göç sonrası "beklediği mutluluk" düzeyine ulaşamayabilir.

Neoklasik iktisat bireylerin göç sırası ve sonrası karşılaşabileceği kültürel farklılıklar, dil problemleri, yalnızlık hissi, yeni bir iş arama, yeni bir işe geçiş ve becerilerin kazanılması süreci, ayrımcılık hissi, sosyal bozulma gibi daha da çeşitlendirebileceğimiz sosyal, kültürel ve psikolojik maliyetleri hesaba katmaz. Örneğin, göç kararı sosyoloji literatüründe belirtildiği gibi sosyal sermaye kaybı ve kültürel kimlik kaybına neden oluyorsa, göçten sonra gelir artışından kaynaklanan fayda artışı, sosyal sermaye kaybı ve kültürel kimlik kaybı nedeniyle de azalacaktır (Schnittker, 2008: 233-259). Bu halde dikkat edilmesi gereken nokta bireyin göç sonrası yaşayacağı psiko-sosyal maliyetlerin gelir artışının getireceği kazançları aşıp aşmayacağıdır.

Göçün temel amaçlarından biri daha iyi bir yaşam arzusudur. Bunun yolu ise gelir artışından geçer. Göç kararlarının altında genel olarak bu güdü yatsa da gelir dışında eğitim, yeni heyecan arama isteği, huzurlu ve güvenli bir ortam arayışı gibi pek çok faktör mevcuttur (Bartram, 2015: 1213-1215).

Ana akım iktisat fayda maksimizasyonunun öneminden bahsederken bireylerin bunu gelir yolu ile sağladıklarını belirtmektedir. Bireyler gelirlerini arttırmak yolu ile objektif iyi oluşlarını arttırırlar. Ancak son yıllarda mutluluk literatüründe ve bu alanda yapılan çalışmalarda bireylerin genellikle "mutlak" gelirden ziyade "nispi" gelire önem verdikleri ve göç kararlarının da genellikle "nispi gelir" kaygısı ile alındığı ortaya çıkmıştır (Bartram, 2015: 1214). Mutluluk çalışmaları belirli bir gelir düzeyinden sonra daha fazla gelir artışının daha fazla mutluluğa neden olmadığını göstermektedir. Gelir artışının düşük gelir düzeyine sahip olan bireylerde temel ihtiyaçların karşılandığı nokta olarak ifade edilen gelir düzeyinden sonra mutluluğu arttırmadığı tespit edilmiştir (Bartram, 2013b: 157). Örneğin, Şekil 2'de görüleceği üzere 1900'lü yılların ikinci yarısından itibaren Japonya'nın ekonomik çıktısının katlanarak artmasına rağmen, ortalama mutluluk düzeyinde belirgin bir artış yaşanmadığı gözlenmiştir (Easterlin, 2005: 243255). 
Grafik 2. Japonya'da Gerçek Mutluluk 1958-1987

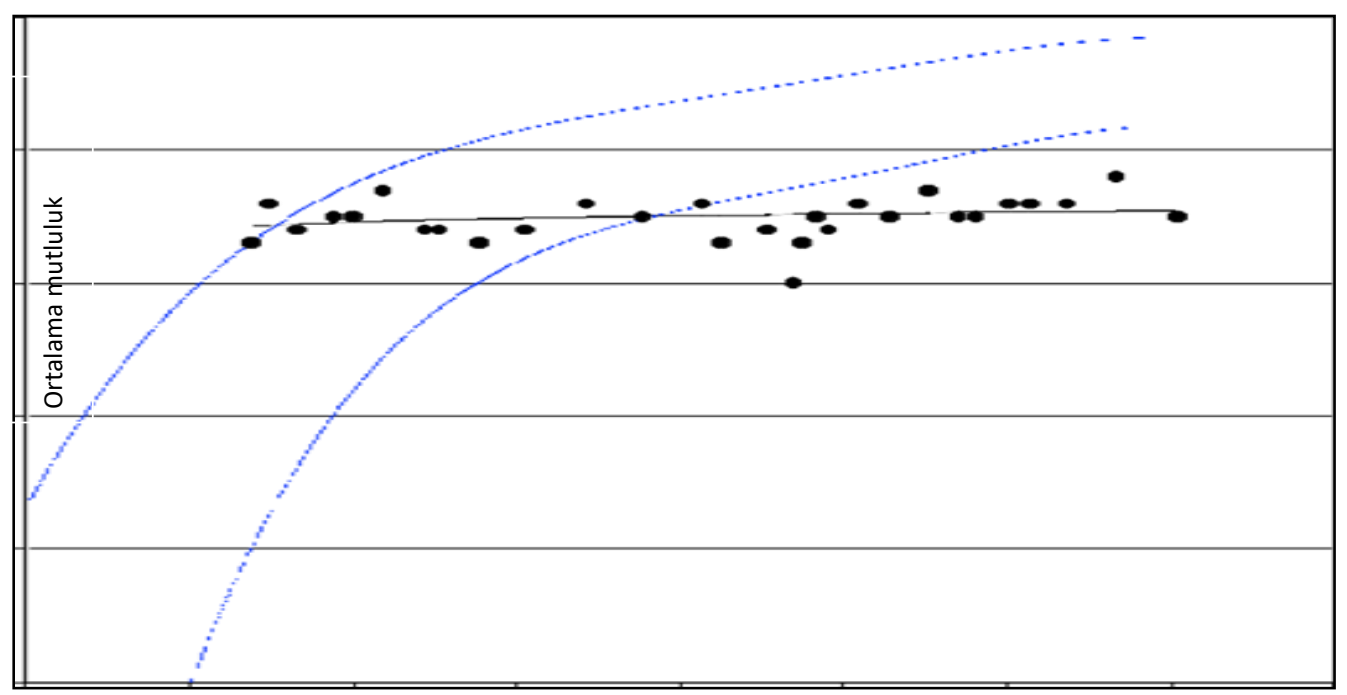

Kişi Başına GSMH

Kaynak: Easterlin, 2015: 243-255.

\subsection{Sosyal Karşılaştırma, Adaptasyon, İstekler ve Göç}

Mutluluk çalışmalarında genellikle zengin ülkelerde yaşayan bireylerin yoksul ülkelerde yaşayan bireylere oranla, Kolombiya, Vietnam, İtalya, İspanya gibi istisnalar hariç, daha mutlu oldukları tespit edilmiştir. Daha fazla gelirin daha fazla mutluluk getirmemesi ve zengin ülkelerdeki bireylerin fakir ülkelerdeki bireylere göre daha mutlu olmaları gibi iki farklı sonuç arasındaki çelişki araştırmacıları bu iki konuyu araştırmaya ve açıklamaya yöneltmiştir. Literatürde bu çelişkili durum üç psikolojik etkiyle açıklanmaktadır. Birincisi, sürekli ve tekrar eden uyarıılar zamanla azalan bir etkiye sahiptir (aldığımız bir şeyden duyulan hazzın zamanla düşmesi). íkinci olarak mutluluk doğrudan gelir ile ölçülemez fakat amaç ve arzuları karşıladığı ölçüde fayda sağlar. Üçüncüsü ise, gelirin getirdiği mutluluk karşılaştırma ile anlam kazanır. İnsanlar diğer insanlara göre daha fazla gelir sahibi oldukları ölçüde mutlu olurlar, yani mutlak miktardan ziyade görece zenginlik önemlidir (Easterlin, 1974: 89-125). Bu üç psikolojik etki mutluluk literatüründe oldukça önemli bir yere sahip olan sosyal karşılaştırma, adaptasyon ve istekler gibi kavramları karşımıza çıkarmaktadır. Sosyal karşılaştırma, adaptasyon teorisi ve istekler göç ile yaşam memnuniyeti arasındaki ilişkiyi anlamamıza yardımcı olabilir.

İlk kez Festinger (1954) tarafından ortaya atılan Sosyal Karşılaştırma Teori'sine göre bireyler kendi fikir ve becerilerini değerlendirme ve dolayısıyla kendilerini başka kişilerin fikir ve kabiliyetleri ile karşılaştırma ihtiyacı hissederler (Gemlik vd., 2007: 58). Bireylerin yapmış oldukları karşılaştırmanın yönü ise 3 türdür (Gökdemir Dumludağ, 2011: 51).

- Bireyin kendisinden daha düşük nitelikli, daha kötü performansı olan kişilerle yaptığı aşağıya doğru karşılaştırma.

- Bireyin kendisinden daha üstün nitelikli, daha iyi performansa sahip kişilerle yaptığı, yukarıya doğru karşılaştırma.

- Bireyin kendisi ile aynı nitelikte ve aynı performansa sahip kişilerle yaptığı yatay karşılaştırma. 
Teoriye göre eğer kişi kendini kıyasladığı insanlardan daha fazla gelir elde ediyorsa mutluluğun arttığını tersi durumda ise mutluluğunun azaldığını söylemektedir. Bireyler kendilerini kendilerine benzer insanlarla karşılaştırma eğilimindedirler (Clark vd., 2008: 106). Örneğin Senik, 25 ülkenin verilerini kullanarak yaptığı çalışmasında bireylerin genellikle kendilerini meslektaşları ve eski okul arkadaşları ile karşılaştırdıkları sonucuna varmıştır (Senik, 2009: 24).

Yaşam kalitesi alanında oluşturulan sosyal karşılaştırma teorisi Easterlin tarafından geliştirilmiştir. Easterlin çalışmasında bireyin kendi gelirini sosyal çevresinin geliri ile kıyasladığını belirtmektedir. Birey sosyal çevresindeki gelirden daha fazla gelir elde ediyorsa bireyin mutluluğu artmakta tersi durumda ise azalmaktadır (Easterlin, 1974: 89-125). Birey kendisini çok kazanan birisi ile karşılaştırıp mutsuz olabilir ya da istek düzeyini yükselterek kazanmayı hedeflediği gelir düzeyini arttırabilir (Boyce vd., 2010: 471-5). Dolayısıyla Easterlin mutlak gelir artışını ortalama mutluluğu arttıran bir faktör olarak görmemektedir (Bartram, 2013b: 156-175). Göç nedeni ile bireylerin kendilerini karşılaştırdıkları referans gruplar değişebilir. Göçmenler kendilerini göç ettikleri ortamdaki yeni akranlarıyla karşılaştırmaya başlayabilirler (Melzer vd., 2012: 2-9). Göçmenin göreli mutluluğu tamamıyla kendisini karşılaştıracağı referans grup ile ilişkili olduğu için göç çalışmalarında araştırma yaparken bu referans grupların tespitinde oldukça dikkatli olunmalıdır (Simpson, 2012: 10-18).

Easterlin Paradoksu dikkate alındığında zengin ülkelerden daha yoksul ülkelere göç bize ilginç bir sonuç verir. Göç eden kişi varışülkesinde göç etmeden önceki gelirine göre daha düşük "mutlak gelir" elde edebilir. Fakat bu kişinin varış ülkesindeki ${ }^{3}$ sosyo-ekonomik hiyerarşi içindeki konumu kaynak ülkesindeki (origin country) konumuna göre daha yüksek olabilir. Eğer öyleyse bu durumda bireyin mutluluğunun artması beklenmektedir. Eğer para nispi anlamda önemli ise, daha zengin bir ülkeye göç etmek kişinin mutluluğuna zarar verebilir (özellikle göçmen varış ülkesinde daha düşük bir ekonomik ve sosyal statüye sahipse). Bu nedenden ötürü mutlak gelirdeki artışa rağmen bireyin mutluluğunun düştüğü gözlenmektedir. Özellikle bireyler kendilerini varış ülkesindeki insanlarla kıyaslarlarsa mutlak gelirleri artsa bile mutluluklarının varış ülkesi yerel halkına göre (natives: yerliler) daha düşük olduğu gözlemlenmiştir (Bartram, 2013a). Birey, çıkış ülkesi (source or origin country) daha fakir olduğu için kendisini bu ülkedeki insanlarla karşılaştırırsa daha mutlu, yeni ve daha zengin olan varış ülkesindeki (destination country) insanlarla karşılaştırırsa daha mutsuz olmaktadır. Bireyler göç etmeden önce muhtemelen kendilerini halkından oldukları ülkedeki bireylerle kıyaslamaktadır. Ancak göç ettikten sonra referans gruplarını değiştirip, kendilerini varış ülkesindeki insanlarla kıyaslamaya başlayabilirler. Referans grubundaki bu değişimin onların subjektif iyi oluşlarında olumsuz yönde değişime yol açması muhtemeldir. Sosyal karşılaştırma hipotezleri bu nedenle göçmenlerin göç sonrası subjektif iyi oluşlarındaki kazanımlarda bir azalma öngörmektedir. Subjektif iyi oluşlarındaki düşüş yeni şartlardaki ekonomik uyum düzeyine bağlıdır.

Daha hızlı uyum sağlayan ${ }^{4}$ ve referans grubunu daha çabuk değiştiren göçmenler kendilerini yeni grupla (yani varış ülkesindeki insanlarla) karşılaştıracakları için subjektif iyi oluşları da

\footnotetext{
${ }^{3}$ Natives; Ülkenin yerlileri, Stayers: Kalanlar (göç etmeyenler); Origin Country: Memleket, menşei ülke, kaynak ülke, çıkış ülkesi; Destination Country: Varış ülkesi, Hedef ülke.

${ }^{4}$ Burada sözü geçen daha hızlı uyum sağlayan bireyler, genellikle geride bıraktıkları ülkede belirli bir gelir düzeyine ulaşmış ve eğitim seviyesi yüksek bireylerdir. Bu nedenle adaptasyonları daha hızlı olmaktadır.
} 
düşmektedir. Ekonomik adaptasyon hızı düşük ${ }^{5}$ olan, yani diğer bireylere göre daha düşük kazanca sahip olan ve varış ülkesi halkına göre nispeten daha yoksul olan bireylerin gittikleri ülkedeki subjektif iyi oluşları da daha düşük olacaktır (Melzer vd., 2012: 2-9).

1989 yılında Doğu ve Batı Almanya'nın birleşmesinden sonra Doğu Almanya'dan Batı Almanya'ya yönelik göç hareketinde adaptasyon, sosyal karşılaştırma ve göreli yoksunluğun mutluluk üzerindeki etkisinin incelendiği bir çalışmanın sonuçlarına göre kadın göçmenler beklenmedik bir biçimde sosyal karşılaştırma ve adaptasyondan pozitif olarak etkilenmiştir. Ayrıca çalışmanın diğer sonuçlarına göre göçmenler Batı Almanya'ya göç sonrasında, kendi kazançları ile varış ülkesindeki meslektaşlarının kazançlarını karşılaştırmaktadırlar. Erkek göçmenlerin yeni meslektaşlarıyla kendilerini karşılaştırılmaları yaşam memnuniyetlerini olumsuz etkilemekte ve göçün pozitif etkisini güçlü bir şekilde bastırmaktadır. Göçmen kadınlarda ise göç sonrası gelir artışı yaşam memnuniyetlerini olumlu yönde etkilemektedir (Melzer vd., 2012: 24).

Sosyoloji, psikoloji ve refah ekonomisi gibi alanlarda yapılan mutluluk çalışmaları bize bireyin yaşam alanındaki yeni duruma uyum sağlaması anlamına gelen adaptasyonun da yaşam memnuniyetini güçlü bir şekilde etkilediğini belirtmektedir (Melzer vd., 2012: 2). Adaptasyon teorisi, genellikle bireylerin yeni bir duruma adapte olduğunu, örneğin parasal gelirdeki bir artış sonucunda bireyin yaşam memnuniyeti ilk etapta artsa bile daha sonra (çoğunlukla) hızlı bir şekilde eski haline döneceğini söylemektedir (Melzer vd., 2012: 6-7). Yapılan araştırmalar göstermektedir ki piyango kazanmak, servet kaybetmek, işe alınmak ya da işten kovulmak gibi olayların hiçbirinin yaşam memnuniyeti üzerinde bir kaç aydan daha fazla etkisi bulunmamaktadır. Çünkü bireyler kaçınılmaz olarak ve hızlı bir şekilde yaşamdaki olaylara adapte olmaktadırlar. Yaşamdaki olaylar ve yaşam memnuniyeti üzerine yapılan ilk çalışmada piyango kazananlar ve belden aşağısı felçli kişiler birbirleriyle karşılaştırılmıştır. Elde edilen sonuçlara göre bu iki grup arasındaki fark umulduğundan daha az çıkmış ve adaptasyon teorisinin temel varsayımı haline gelmiştir (Luhmann vd., 2012: 592). Örneğin; bireyin evliliğe verdiği ilk tepki pozitiftir. Fakat ortalama iki yıl içerisinde adaptasyon süreci çok hızlı bir şekilde tamamlanmaktadır. Bunun aksine sakatlık başlangıcı, dulluk ve boşanma gibi negatif olaylara karşı gösterilen adaptasyon hızının çok daha yavaş gerçekleştiği tespit edilmiştir. Bulgularda elde edilen sonuçlardan en çarpıcı olanı işsizlikle ilgilidir. İşsiz kaldıktan sonra bireylerin yaşam memnuniyetleri önemli ölçüde düşüş göstermektedir. Bireyler yeniden işe girmeyi başarsalar bile bu durum devam etmektedir. Tekrarlanan işsizlik ise bu etkinin şiddetini arttırmaktadır (Luhmann ve Eid, 2009; Lucas, 2005).

Kısaca teori, gelirinde bir değişiklik yaşayan insanların zamanla değişime alıştığını ve bu değişimin yaşam memnuniyeti üzerindeki pozitif etkisinin silindiğini yani bir başka deyişle objektif yaşam koşullarında meydana gelen değişiklikten sonra bireylerin önceki mutluluk düzeylerine geri döndüklerini belirtmektedir.

Ekonomideki mutluluk literatüründe Easterlin Paradoksu'nda gelir artışı ile mutluluk artışı arasında zayıf bir ilişki olduğu öne sürülmektedir. Easterlin'in tezi, zengin ülkelerde gelir ve mutluluk arasında ilişkinin zayıf olduğu gerçeğine dayanmaktadır. Örneğin 1990'lar boyunca ABD'de bireylerin gelirlerindeki artışa rağmen mutluluklarında belirgin bir artış yaşanmamıştır

5 Burada sözü geçen adaptasyon hızı düşük olan bireyler, genellikle geride bıraktıkları ülkede de düşük gelir düzeyine sahip ve eğitim seviyesi düşük bireylerdir. Bu nedenle referans grupları kolay değişmez ve adaptasyonları çok daha yavaş olmaktadır. 
(Blanchflower, 2004: 1359-1386). Paradoksun kendisi için Easterlin tarafından yapılan açıklama ise adaptasyon teorisine dairdir. Easterlin'e göre bireyin geliri arttığı zaman ilk etapta mutluluğunda da bir artış meydana gelmekte fakat daha sonra birey kısa bir süre içerisinde tekrar eski mutluluk seviyesine geri dönmektedir (Clark vd., 2008: 104).

Göçmenlerin yaşam memnuniyeti üzerine giderek artan literatür göstermektedir ki, bireyler göç sonrası yüksek gelir elde etseler bile yaşam memnuniyetleri azalabilmektedir. Bu görünür paradoksun nedeni olarak "adaptasyon teorisi" gösterilmektedir. Yani mutluluk sadece gelire bağlı değil, aynı zamanda bireyin isteklerine ve hedeflerine de bağlıdır (Knight vd., 2010: 113124).

Bireylerin mutlak gelirleri artsa bile göçmenlerin istek düzeyi yeni çevrelerindeki yüksek gelirli insanları referans almaları nedeniyle artabilir. Bunun sonucu olarak, bu karşılanmamış beklenti ve istekler bireylerde hayal kırıklığına ve yaşam memnuniyetlerinde azalmaya neden olabilir. Örneğin; Knight ve Gunatilaka (2012) tarafından Çin'de kırsal bölgeden kentsel bölgeye göç sonucunda bireylerin öznel iyi oluşlarının beklenmedik şekilde azalacağı öne sürülmüş ve bunun nedeni olarak da bireylerin istek düzeylerinin gelirlerinden daha fazla artması gösterilmiştir.

\subsection{Dünyadaki Mutluluk- Göç Araştırmaları}

Göçmenlerin yaşam memnuniyetleri ile ilgili yapılan çalışmaları odaklanılan konulara göre ana hatlarıyla "göç eyleminin bireyin mutluluğunu arttırıp arttırmadığı" ve "varış ülkesi halkı ile göçmenler arasındaki mutluluk farkı"na bakılan çalışmalar olarak sınıflandırılabiliriz (Hendriks, 2015: 344-350).

Illk olarak Polgreen ve Simpson'ın (2011) çıkış ülkesinin mutluluğu ile göçmenlerin mutluluğu arasındaki ilişkiyi analiz ettikleri çalışmadan elde edilen sonuçlara göre, mutluluk seviyesi 3'ün altında olan ülkelerde gelir seviyesi arttıkça insanların göç etme motivasyonları düşmekte, mutluluk seviyesi 3'ün üstündeki ülkelerde ise gelir seviyesi arttıkça insanların göç etme motivasyonları artmaktadır.

Grafik.3 Mutluluk ve Göç Arasında Öngörülen Ilişski

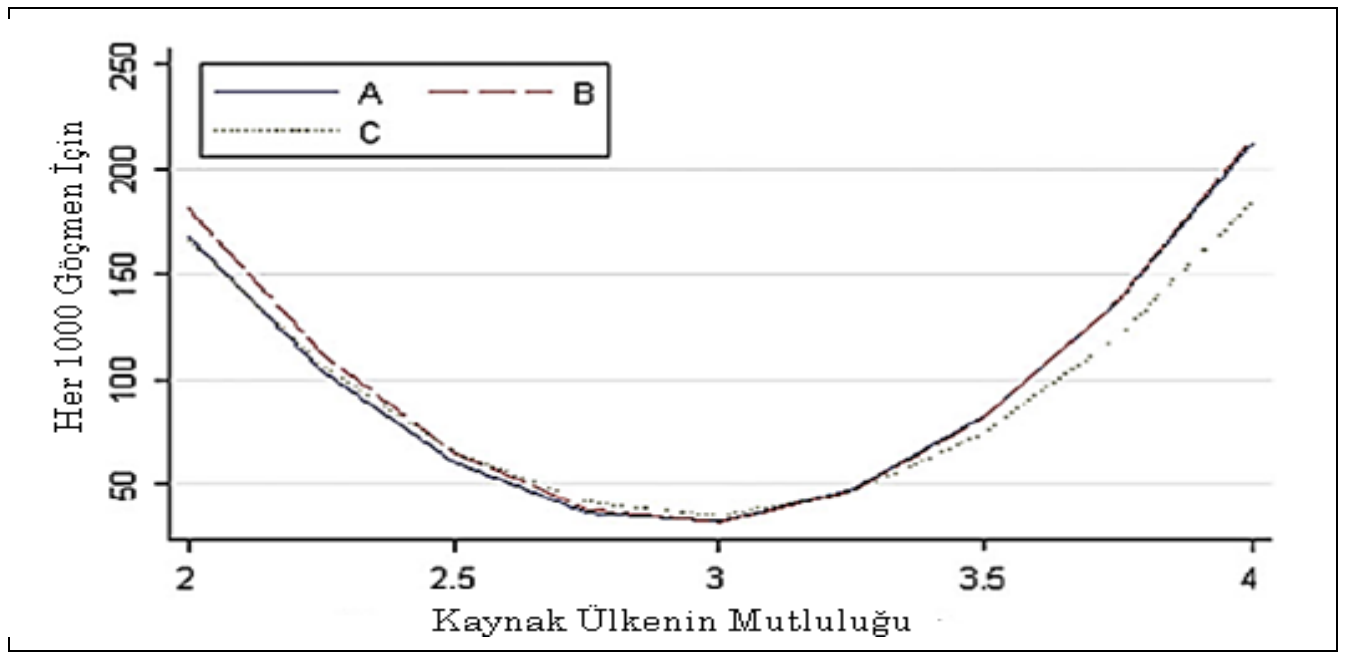

Kaynak: Polgreen ve Simpson, 2011: 828-834. 
Çalışmada belirli bir mutluluk seviyesi altında (2.97 civarı), göç verme ve mutluluk arasında negatif ilişki olduğu tespit edilmiştir, yani çıkış ülkesinin mutluluğu arttıkça göç verme oranı düşmektedir. Fakat bu mutluluk sınırının üstünde ise göç verme ve mutluluk ilişkisi pozitif olmaktadır, yani mutluluk arttıkça göç verme oranı artmaktadır. Bu durum göç verme ve göç veren ülkenin mutluluğu arasında U-şekilli bir ilişkiye sebep olmaktadır.

Bir diğer çalışma ise bu U şekilli ilişkiyi açıklamaya çalışmaktadır. Söz konusu çalışmaya göre mutluluk ve göç konusunda, mutlu ülkelerdeki insanlar belirli bir mutluluk seviyesine zaten ulaştıkları için mutsuz insanlara göre "göç etmeyi" daha farklı algılıyor olabilirler. Örneğin; görece mutlu ülkelerde mutluluktaki artış daha yüksek göç verme oranı ile ilişkilendirilebilir. Çünkü bu kategorideki insanlar risk almaya daha yatkındırlar ve bu yüzden kolayca göç edebilirler. Ayrıca bu bireyler hayata daha iyimser bakmaktadırlar ve bu nedenle yurtdışında bulunan daha iyi fırsatların peşinden gitme eğilimleri de artmaktadır. Fakat görece daha mutsuz ülkelerde, bireylerin mutluluklarındaki artış kendi ülkelerindeki maddi ve sosyal konumlarını yükselteceği için ülkede kalmayı daha fazla tercih edebilirler ve bu da ülkelerin göç verme oranlarını düşürebilir. Bu kategorideki insanlar göç etmeye daha soğuk bakabilir ve riskli bulabilirler (Polgreen vd., 2010: 828-834). Yine aynı çalışmanın devamında, sadece ABD'ye olan göçü göz önünde bulundurarak (sadece $A B D$ verilerini kullanarak) analizi yeniden yaptıklarında yukarıdaki analiz sonuçlarını destekleyecek yönde $U$ şekilli bir ilişki tespit edilmiştir.

Ratha vd. (2007) göçmen akımının önemli bir kısmının bilinenin aksine farklı bir yol izlediğini ve aynı ekonomik çalışma düzeyine sahip bir ülkeden diğerine göç etme eğilimine sahip olduğunu belirtmektedir. Üstelik göçmenler bazen de kendi ülkelerinden daha düşük gelirli bir ülkeye taşınabilmektedirler. Fakat bu durum genellikle yaygın değildir (Bartram, 2013a).

IOM (2013) araştırmaları sonucu az gelişmiş ülkelere doğru ya da az gelişmiş ülkeler arasında göç eden bireylerin genelde yaşamlarından daha az memnun oldukları, buna karşılık gelişmiş ülkelere doğru ya da gelişmiş ülkeler arasında göç eden bireylerin hayatlarından daha memnun oldukları görülmüştür. Bartram'ın bulguları IOM'nin çalışmaları ile uyumludur. Daha az gelişmiş olan Güney Avrupa'ya göç eden Batı Avrupalılar, göç etmeyen Batı Avrupalı akranlarına nazaran daha az mutludurlar. Örneğin; Bartram (2013c: 416-22), ESS verisini kullanarak Batı Avrupa'ya göç eden Romanyalı göçmenler ile göç etmeyen (stayers, kalanlar) Romanyalıları karşılaştırdığı çalışmasında bu iki grubun mutluluk düzeylerinin benzer olduğunu belirtmiştir. Ayrıca ülkelerine geri dönen göçmenlerin hiç göç etmeyenlerden daha mutsuz oldukları da tespit edilmiştir. Bartram'ın 2010 yılında yaptığı bir diğer çalışmada; ABD'ye fakir ülkelerden göç eden bireylerin, zengin ülkelerden göç eden bireylere göre daha mutsuz oldukları tespit edilmiştir. Avrupa ve Kanada gibi gelişmiş ülkelerden gelen bireyler neredeyse Amerika doğumlu bireylerle aynı mutluluk düzeyine sahiptir. Fakat Asya, Latin ABD ve Afrika gibi daha az gelişmiş ülkelerden gelen insanların yaşam memnuniyetlerinin ise daha düşük olduğu gözlemlenmiştir. Buna göre, ekonomik amaçlı göç sonucu bireylerin objektif koşullarının iyileşmesi bireyin mutluluğunun artması için gerekli fakat çoğu zaman tek başına yeterli değildir. Örneğin; ABD göçmenler için daha iyi yaşanılacak bir yer olabilir fakat aynı zamanda ülkedeki mental hastalıkların oranı fakir ülkelere göre çok daha fazla olmakla birlikte bireysellik, sosyal izolasyon, karakter çözülmesi ve bozulması, dışlanma, yoksunluk hissi, uzun çalışma saatleri gibi problemler de mevcuttur (Bartram, 2010: 354-356). Bartram'ın Kuzey Avrupa ülkelerinden (Belçika, İsviçre, Fransa, Almanya, Britanya ve Hollanda) Güney Avrupa ülkelerine (İspanya, Portekiz, Yunanistan ve Kıbrıs) göç eden insanların mutluluğunu incelediği çalışmasının sonuçlarına göre göçmenler göç ettikleri ülkede (destination country) göç etmeyen insanlara (stayers) göre daha mutsuzdurlar 
(Bartram, 2013a). Yani bireyler daha gelişmiş Kuzey Avrupa ülkelerinden görece daha az gelişmiş Güney Avrupa ülkelerine göç ettikleri zaman, göreli ekonomik pozisyonları beklentilerini karşılayacak ölçüde artmayabilir. Göçmenler kendilerini hala geride bıraktıkları gelişmiş ülkedeki bireylerle kıyaslıyor olabilirler ya da göçmenin göç sonucu ortaya çıkan kayıpları göç sonucu elde ettiği kazançlarını aşmış olabilir.

Doğu Almanya'dan bireylere sunulan ekonomik koşullar ve daha iyi iş olanaklarına sahip olan Batı Almanya'ya göç eden bireylerle ilgili olarak panel verilerle yapılan bir çalışmada, Doğu Almanya'dan Batı Almanya'ya göç edenlerin daha iyi iş olanakları bulmaları yüzünden daha mutlu olduklarını tespit edilmiştir. Bu bulgular yüksek kalitede verilerle yapıldığı için önemlidir. Bu çalışma açıkça göstermektedir ki daha zengin bir bölgeye göç mutluluk üzerinde daha pozitif sonuçlara neden olmaktadır. Ancak yazar bu çalışmada elde edilen sonuçların tamamen farklı bir dil ve kültüre sahip bir başka ülkeye göç eden bireyler içinde genelleştirilemeyeceğini ve bu konunun araştırılmaya değer olduğunu vurgulamıştır. (Melzer, 2011: 73-92).

Bir diğer çalışmada ESS verileri kullanılarak Bulgaristan, Hırvatistan, Çek Cumhuriyeti, Estonya, Macaristan, Litvanya, Polonya, Romanya, Rusya, Slovenya, Slovakya, Türkiye ve Ukrayna'dan göç edenler ile bu ülkelerde kalanlar arasındaki mutluluk farkına bakıldığında, göç edenlerin kalanlara göre daha mutlu oldukları gözlenmiştir. Ülke bazında bakıldığında Polonya (mutluluk ortalaması Doğu Avrupa ülkelerine göre yüksek) için göçmenler ve kalanlar arasında bir mutluluk farkından bahsedilmezken, Doğu Avrupa ülkelerine göre mutluluk ortalamaları daha düşük olan Romanya, Türkiye ve Rusya için göç edenlerin kalanlardan çok daha mutlu olduklarını söylemek mümkündür. Burada ayrıca varış ülkesi de önem arz etmektedir (Bartram, 2013b: 163-168). Finlandiya, Almanya, Norveç, İspanya, İsveç ve İsviçre'ye giden Doğu Avrupalı göçmenler için pozitif yönde bir mutluluk farkı söz konusu iken, İrlanda ve Yunanistan gibi görece daha zor şartlara sahip ülkelere giden göçmenlerde ekonomik sıkıntılardan ötürü bir mutluluk farkı tespit edilememiştir.

Mutluluk alanında yapılan göç çalışmalarına yönelik araştırma sorularından biri göçün mutluluğu arttırıp arttırmadığına dairdir. Aynı zamanda mutluluk-göç literatürüne göre, farklı ülkelerden gelen insanların çıkış ülkesinin gelişmişlik düzeylerine göre göç sonrası yaşam memnuniyetleri farklı olabilir.

Stilman vd.'nin yaptıkları deneysel bir çalışmada Tonga'dan Yeni Zelenda'ya taşınmak isteyen katılımcıların bir kısmına çekilişle göç etme izni verilmiş, bir kısmı ise göç etme iznini alamamıştır. Bu doğal deney sonucunda, Tonga'dan Yeni Zelanda'ya taşınan şanslı göçmenler ile Tonga'da kalan diğer katılımcıların göçten sonraki bir yıl için mutluluk düzeyleri karşılaştırıldığında aynı mutluluk düzeyine sahip oldukları görülmüştür. Göç edenlerin zamanla daha mutsuz hale geldikleri gözlenirken, objektif iyi oluşlarında ise belirgin bir artış olduğu gözlenmiştir. Örneğin göç edenlerin ücretleri, göç edemeyenlerin ücretlerinin neredeyse üç katıdır. İkinci ilginç farklılık ruhsal sağlık (mental) ve mutluluk arasındadır. Tonga göçmenlerinin akıl sağlığı yirmi puanlık bir skalada yaklaşık üç puan artmasına rağmen mutluluklarında düşüş yaşandığı tespit edilmiştir (Stillman, 2015: 73-92). Bu sonuçlar da yine sadece gelir artışının mutluluğu arttırmayacağı yönündeki literatürü destekleyecek niteliktedir. Finlandiya'ya göç eden Rus diasporası için göç etmeden bir yıl öncesi ve göç ettikten sonraki bir yıl için yapılan araştırmada göçmenlerin yaşam memnuniyetinin arttığı tespit edilmiştir. Fakat bu çalışmanın sonuçlarına bakarak genel bir kanıya varmak tehlikeli olabilir. Çünkü buradaki panel veri göçten hemen önceki bir yılı aldığı için, örneğin göç etme kararı alan göçmenin ruhsal durumu, göç edecek olmanın verdiği stres veya heyecan sebebiyle bireyin gerçek durumunu yansıtmayabilir. 
Göç ettikten sonraki bir yıl içerisinde bireyin mutluluk düzeyinin artması bir yanılsama ya da geçici bir durum olabilir (Mahonen vd., 2013: 324-33).

Erlinghagen'in 2011 yılında ESS verisini kullanarak Almanya'dan Avrupa'ya göç eden bireyler ile göç etmeyen ve daha önce göç edip geri dönüş yapmış olan bireylerin yaşam memnuniyetlerini karşılaştırdığı çalışmada, göç eden bireylerin yaşam memnuniyetlerinin göç etmeyen ve geri dönüş yapan bireylere göre daha fazla olduğu sonucuna ulaşılmıştır. Çalışma yaşam memnuniyeti arasındaki bu farkın, sosyo-demografik ve sosyo-ekonomik yapıdaki farklııklarla açıklanamadığını, bu farklıığın daha çok bireylerin psiko-sosyal yönlü ve bireysel gelirlerini değerlendirmelerindeki farklılıklardan kaynaklanabileceğini belirtmektedir (Erlinghagen, 2012: 911-920).

Polgreen ve Simpson (2011) makro düzeyde göç ve mutluluk arasında bir ilişki tespit etmişlerdir. WVS verisi (1981-2004) kullanarak yaptıkları çalışma sonucunda göç oranları ve çıkış ülkesinin mutluluğu arasında $U$ şekilli bir ilişki tespit edilmiştir. Çalışma bir eşik etkisi olduğunu destekleyecek sonuçlar ortaya koymaktadır. Mutsuz ülkeler yüksek göç oranlarına sahiptirler, fakat ülkenin mutluluğu arttıkça bu oran düşmektedir (Polgreen vd., 2011: 819-840).

Sosyoloji alanında uluslararası göçmenlerin mutluluğunu araştıran mikro düzeyde çalışmalar da mevcuttur. Illk grup çalışmalar bir ülke içindeki göçmenlerin mutluluklarını karşılaştırmaktadır. Örneğin; Avrupa'dan İsrail'e göç eden yüksek vasıflı göçmenlerin, Eski Sovyetler Birliği ülkelerinden gelen yüksek vasıflı göçmenler ve Etiyopya'dan gelen düşük vasıflı göçmenlere göre yaşamlarından çok daha fazla memnun oldukları tespit edilmiştir. Böylelikle aynı ülkede yaşayan farklı ülke kökenli göçmenler arasında önemli ölçüde mutluluk farkı tespit edilmiştir (Amit vd., 2010: 89-104).

Göçmenlerle ve varış ülkesi halkının karşılaştırıldığı çalışma, Rus göçmenlerin daha iyi eğitim ve daha yüksek sosyo-ekonomik statüye sahip olmalarına rağmen İsrail halkından daha düşük bir yaşam memnuniyetine sahip olduklarını göstermektedir (Ullman vd,. 2001: 449-463).

Bălţătescu'nun çalışmasında göçmenlerin vardıkları ülkenin halkından daha mutsuz oldukları tespit edilmiştir. 13 Batı Avrupa ülkesinin 12 'sinde göçmenlerin varış ülkesi halkından daha mutsuz olduğu rapor edilmiştir. Çalışmada, göçmenlerin etnik kökeninin onların subjektif iyi oluş düzeylerini nasıl belirlediği tartışılmaktadır. Çalışmanın ilginç sonuçlarından birine göre de göçmenler genel olarak varış ülkesi halkından daha mutsuz olmalarına rağmen, bu ülkenin toplumsal ve siyasal koşullardan o ülkede yaşayanlara göre daha memnundurlar (Bălţătescu,2005: 128-143).

Safi (2010), Bălţătescu'nun çalışmalarına (2005 ve 2007) ait verileri tekrar kullanarak Bălţătescu'nun çalışmalarında çıkan sonuçları doğrulamış ve aynı zamanda hem birinci hem ikinci nesil göçmenlerin varış ülkesi halkından daha mutsuz olduğunu tespit etmiştir. Burada şaşırtıcı olan sonuç ise asimilasyonun göçmenlerin mutluluğunu arttırmadığını destekleyecek nitelikte olan, ikinci nesil göçmenlerin birinci nesil göçmenlerden daha mutsuz olduklarına dair sonuçtur. Safi ikinci nesil göçmenlerin de ebeveynleri kadar daha alt yaşam koşullarına sahip olmayı haksızlık olarak gördüklerini belirtmektedir (Safi, 2010: 159-176).

Senik (2014) yine Fransa'da yaşayan birinci ve ikinci kuşak göçmenler için de benzer bir sonuca ulaşmıştır. Ayrıca çalışmada diğer Avrupa ülkelerinde yaşayan Fransız göçmenlerin mutluluklarının, Avrupalı göçmenlerin mutluluk ortalamasından daha düşük olduğu tespit edilmiştir (Senik, 2014: 379-401). Konuya dair diğer çalışmalar da Avrupa ülkeleri dışındaki diğer 
ülkeler için de göçmenlerin yerlilerden daha mutsuz oldukları sonucunu destekleyecek niteliktedir.

Göçmenler arasında mutluluk düzeyinin düşük çıkmadığı çalışmalar da mevcuttur. Göçmenlerin mutluluk düzeyinin yüksek çıktığı çalışmalara dair farklı açıklamalar mevcuttur. Birinci açıklama, göçmenlerin göç etmeden önce ya daha yüksek ya da aynı seviyede mutluluk düzeyine sahip oldukları yönündedir. Yani göçmenlerin göç etmeden önce de mutlu olabilme ihtimali mevcuttur. Problem bu durumun yatay kesit verilerle tespit edilememesidir. "Birey göç etmeden önce zaten mutlu muydu?" yoksa "Bireyin mutluluğu göç sonucunda mı arttı?". Bu nedenle göç öncesi mutluluk düzeyinin bilinmesi önemlidir. Ancak göç öncesi mutluluk seviyesi de her durumdaki sapmayı açıklayamaz. ikinci olarak bazı çalışmalar; gelir, işsizlik ve sağlık gibi aynı zamanda mutluluğu da belirleyen ve zamanla değişen değişkenler içermektedir. Bu nedenle, göçmenlerin gerçekten benzer mutluluğa sahip olup olmadıkları ya da zamanla değişen değişkenlerin bireylerin gerçek mutluluklarını tespit ederken yanıltıcı sonuçlar elde etmemize neden olup olmadıkları konusu belirsizlik taşımaktadır. Mutluluk düzeyinin yüksek çıkması ile ilgili bir diğer açıklama ise göçmenlerin gerçekten yüksek mutluluk düzeylerine erişmiş olmalarıdır (Hendriks, 2015: 353).

Göç literatüründeki bir diğer tartışma alanı, bireylerin kendi yaşamlarını kıyasladıkları referans grup ile ilgili tartışmalardır. Göçmenlerin kendilerini karşılaştırdıkları referans grupların onların yaşam memnuniyeti üzerinde oldukça önemli olduğu tespit edilmiştir. Göç eden bireyin kendisini varış ülkesindeki ya da kendi ülkesindeki bireylerle karşılaştırması, ulusal düzeydeki faktörlerin bireylerin yaşam memnuniyetini nasıl etkilediğini göstermektedir. Örneğin bir ülkede genel yaşam kalitesi baskın faktör ise, daha iyi ekonomik ve sosyal koşullara sahip ülkelere göç eden insanlar çıkış ülkesindeki nüfusa göre daha yüksek; varışülkesindeki bireylere göre (natives) ise neredeyse benzer yaşam memnuniyetine sahip olacaklardır. Sosyal karşılaştırmalar göz önüne alındığında bireyler özellikle kendilerini, kendilerine benzediğini düşündükleri bireylerle karşılaştırırlar. Bu da onların yaşamlarını değerlendirmelerinde daha ılımlı bir etkiye neden olabilir. Göçmenler yurt dışında geçirdikleri zamana bağı olarak, kendilerini kendi halkından olan insanlarla ve de diğer göçmen ve yerli gruplarla karşılaştırma eğilimindedirler.

Gökdemir ve Dumludağ, Hollanda'da yaşayan Faslı ve Türk göçmenleri inceledikleri çalışmalarında, Faslılara göre daha yüksek gelir ve daha düşük işsizlik oranlarına sahip olan Türklerin yaşam memnuniyetlerinin neden daha düşük olduğunu tespit etmeye çalışmışlardır. Çalışma sonuçlarına göre Türk göçmenler için mutlak gelir düzeyinin çok önemli olmadığı, daha çok nispi gelirlerinin önemli olduğu tespit edilmiştir (özellikle Hollandalı halk ile kendilerini karşılaştırarak). Ayrıca Türklerin daha çok gelir ve sosyal statü karşılaştırmaları yapma eğiliminde olmalarından dolayı yaşam memnuniyetlerinin düşük olduğu sonucuna varılmıştır (Gökdemir vd., 2012: 407-417). Aslında, göç sonrası yaşam ağırlıklı olarak ekonomik etmenlere bağlıdır. Bu etmenlerden birincisi, bireyin kendi yetenek ve eğitim seviyesine uygun olan bir işe sahip olması; ikinci olarak beklentilerini karşılayacak bir gelir düzeyine sahip olmasıdır. Ayrıca göç yaşam doyumu, göç edenin kalış süresiyle pozitif olarak ilişkilidir. Kısa süre kalma niyetinde olan göçmenler daha düşük yaşam memnuniyeti seviyesine sahip iken, daha uzun süre kalma niyetinde olan göçmenler ise daha yüksek yaşam memnuniyetine sahiptirler (Schüldeln ve Schüldeln, 2009; Güler ve Poyraz Tacoğlu, 2017).

Göçmenlerin göç ettikleri ülkedeki kalış sürelerinin yaşam memnuniyetleri üzerindeki etkisini araştıran çalışmalar da mevcuttur. Göçmenlerin göç edilen ülkede kalış süresi (kısa ya 
da geçici gibi) tercihlerine bağlı olarak göç öncesi ve sonrası yaşam memnuniyetleri karşılaştırıldığında farklı süreler için yaşam memnuniyetlerinin de farklı olduğu tespit edilmiştir. Bu tür bir karşılaştırma, çoğunlukla uzun süre yurt dışında göç tecrübesi yaşamayan göçmenler için geçerlidir. Çünkü daha kısa süreli göç edenler, şu anki durumlarını göç etmeden önceki durumlarıyla daha çok karşılaştırma eğilimindedirler (Schüldeln ve Schüldeln, 2009: 703-738).

Mirna Safi çalışmalarında yeni bir ülkeye göç ve yeni bir düzen ile birlikte melankoli, üzüntü ve hayal kırıklığının da ortaya çıktığını belirtmektedir (Safi, 2010: 160).

\section{3. Çalışmalarda Karşılaşılan Güçlükler}

Mutluluk-göç alanında yapılan çalışmalarda karşılaşılan en büyük sorunlardan biri, bu konuyla ilgili ayrıntılı olarak uluslararası veri toplayan çok fazla kuruluşun olmamasıdır. Göçmenlerin mutluluğu ile ilgili çalışmalar 2005 yılından itibaren ilgi görmeye başlamış olmasına rağmen göçün dinamik yapısı ve veri elde etmenin güçlüğü gibi pek çok nedenden ötürü bu konuda yapılan çalışmalarda karşılaşılan çeşitli sorunlar mevcuttur.

Subjektif iyi oluş ya da mutluluk alanında en geniş veriye sahip olan kuruluşlardan biri (The World Values Survey) Dünya Değerler Araştırması bireylere ait detaylı göç geçmişini içermemektedir. Katılımcılar doğdukları yeri geldikleri ülke olarak değil bölge olarak bildirmekte ve katılımcılar ülkeye giriş yıllarını spesifik bir tarih olarak değil de bir tarih aralığında bildirmektedir. Ancak bazı ülkelerin kendilerine özgü hem göç hem de mutluluk bilgilerinin olduğu veri setleri mevcuttur. Örneğin; mutluluk literatüründe genişçe kullanılan The British Household Panel Survey ve German Socio-Economic Panel Study gibi göçmenlerle ilgili ayrıntılı bilgi toplayan kuruluşlar bulunmaktadır. Ayrıca The European Social Survey 2003 yılından itibaren yaklaşık olarak 30 ülkede topladığı verilerde göçmenlerin geliş tarihi, doğum tarihi ve ailelerinin doğdukları ülkeyi içeren bilgiler toplamaktadır (Simpson, 2012: 396-398).

Göç çalışmalarında aynı kişi hakkında göç öncesi ve sonrası ayrıntılı bilgi verebilecek çok fazla veri mevcut olmadığından, panel veri eksikliği göç çalışmalarında yaşanan en büyük problemlerden biridir. Bu nedenle göç çalışmaları çoğunlukla açıklayıcılık gücü panel veriye göre çok daha kısıtlı olan yatay kesit verilerle yapılmaktadır. Ancak panel veri ile yapılan çalışmaları esas alarak çıkarımlar yaparken de oldukça dikkatli olmak gerekir. Literatürde mutsuz insanların çoğunlukla yeniden göç ettiği düşünüldüğünden, veri toplarken mutsuz göçmene denk gelme olasılığı mutlu bir göçmene denk gelme olasılığından fazladır. Bu sakınca yatay-kesit verilerle yapılan çalışmalar için de geçerlidir (Hendriks, 2015: 4).

Mevcut çalışmalarda, göç etme düşüncesinin ve eyleminin bireyin göçten önceki ve sonraki bir kaç yıl boyunca mutluluk düzeyinde belirgin bir hareketlilik yarattığı tespit edilmiştir. Dolayısıyla boylamsal çalışmalarda, göç etme gibi bireylerin yaşamlarında meydana gelen büyük değişikliklere adaptasyon süreçlerinde mutluluk çok değişken ve hassas olmaktadır. Ekonomik nedenlerle göç edenlerin hayattan tatmin düzeyleri göçten yaklaşık üç yıl önce düşmeye başlar ve göç ettikten kısa bir süre sonra zirveye ulaşır. Dolayısıyla boylamsal çalışmalar göçmenleri göç etmeden önceki ve sonraki bir kaç yıl boyunca izleyerek yapılmalıdır (Hendriks, 2015: 4).

Yine genetik faktörler gibi gözlenemeyen değerlerin önemli düzeylerde olması da çalışmalarda karşılaşılan problemlerden biridir (Lykken vd., 1996: 186-189). Bu nedenlerden ötürü ortaya çıkan metodolojik problemleri azaltmak için çeşitli yöntemler (iki durumlu kesikli tercih modelleri, çok durumlu kesikli tercih modelleri) kullanılmaktadır. Fakat bu yöntemlerin de ortaya çıkan problemleri tamamen ortadan kaldırdığı söylenemez. Bu nedenlerle göçmutluluk çalışmalarında yatay kesit verilerin panel verilere göre açıklayıcı gücünün çok daha 
sınırlı olduğu kabul edilmeli ve uluslararası çapta daha sağlıklı veriler elde edilerek çalışmalarda ortaya çıkan problemlerin en aza indirgenmesi için çözümler aranmalıdır (Melzer 2011; Voicu ve Vasile 2014).

\section{Sonuç}

Bu çalışmada 21.yüzyılın sosyal, ekonomik ve kültürel boyutlarıyla en çok tartışılan konularından biri olan göç üzerine mutluluk ekonomisi alanında yapılan çalışmalara dair bir literatür özeti sunulmuştur.

Neoklasik Göç Teorisi'ne göre, göç öncesi ve sonrası süreç hakkında tam ve eksiksiz bilgiye sahip olan rasyonel bireyler, göç kararı alırken fayda-maliyet hesabı yapmaktadırlar. Aynı zamanda birey, kendi çıkarları doğrultusunda diğer tüm kültürel ve psikolojik etkileri göz ardı ederek hareket etmekte ve bu doğrultuda göç kararı almaktadır. Neoklasik kuram bireyin gelir yolu ile faydasını arttırdığını belirtmektedir. Bireyler bir başka ülkeye göç ettiklerinde neoklasik iktisadın iddia ettiği gibi yalnızca gelirlerini arttırarak kolaylıkla mutlu olamazlar. Göçün maddi külfetinin yanında ayrıca bir de bu kuramın ihmal ettiği sosyal, kültürel, psikolojik vs. maliyetleri de mevcuttur.

Mutluluk-göç literatüründe yapılan çalışmalarda genellikle bireylerin yaşam memnuniyetleri üzerinde yalnızca gelirin değil, gelir dışında diğer sosyo-demografik, psikolojik, kurumsal vb. faktörlerin de etkili olduğu tespit edilmiştir (nispi gelir, dışlanma, ayrımcllık, hükümet politikaları, cinsiyet gibi). Ayrıca mutluluk-göç literatüründe yapılan çalışmalarda, bireylerin göç sonrası kendilerini karşılaştırdıkları referans grupların değişmesi, bireylerin göç ettikleri ve geride bıraktıkları ülkeler arasındaki gelişmişlik farkı ya da bireyin göç sonrası adaptasyon süreci gibi pek çok nedenin göçmenlerin yaşam memnuniyeti üzerinde etkili olduğu tespit edilmiştir.

Göç konusunda yapılan çalışmalara genel olarak baktığımızda, göçün mutluluk üzerindeki etkisini ya da göç sırası ve göç sonrası mutluluğu nelerin ne yönde ve ne derece etkilediğini anlayabilmemiz için daha ayrıntılı araştırmalara ihtiyaç olduğu görülmektedir. Göç dinamik yapısı itibari ile kaliteli ve güncel veri elde edilmesi güç bir alandır. Bu alanda yapılan çalışmaların birçoğunda yatay kesit veriler kullanılmıştır. Göç alanında ayrıntılı sorular içeren panel verilere intiyaç duyulmaktadır. Bu nedenle uluslararası veri toplayan kuruluşlara nitelikli veri toplanması için büyük rol düşmektedir. Bu alanda yapılacak ayrıntılı çalışmalar sonucu göçmenler hakkında daha fazla bilgi edinmek hükümetlere göçmenlerin refahının arttırılması ve daha sağlıklı göçmen politikalarının yapılması konusunda yol gösterici olabilir. 


\section{Eskişehir Osmangazi Üniversitesi iiBF Dergisi}

\section{Kaynaklar}

Amit, Karin; Howard, Litwin (2010), "The Subjective Well-Being of Immıgrants Aged 50 And Older in Israel." Social Indicators Research. Vol.98 No.1: 89-104.

Bălţătescu, Sergiu (2005), "Subjective Well-Being Of Immigrants In Europe. A Comparative Study, Europe and Their Evaluation of Societal Conditions. An Exploratory Study", University of Oradea Publishing House, Oradea, 128-143.

Bartram, David (2010), "International Migration, Open Borders Debates, And Happiness", International Studies Review Vol.12, No.3: 339-361.

Bartram, David (2013a), "Happiness Among North-To-South Migrants in Europe", Available at SSRN: https://ssrn.com/abstract=2290154 or http://dx.doi.org/10.2139/ssrn.2290154, (Erişim: 30.10.2018).

Bartram, David (2013b), "Happiness And 'Economic Migration': A Comparison of Eastern European Migrants And Stayers", Migration Studies, Vol.1 No.2: 156-175.

Bartram, David (2013c), “"Migration, return, and happiness in Romania", European Societies, Vol. 15 No. 3: 408-422.

Bartram, David (2015), "Inverting the Logic of Economic Migration: Happiness Among Migrants Moving From Wealthier to Poorer Countries in Europe", Journal of Happiness Studies, Vol.16 No. 5: 1211-1230.

Blanchflower, David G; Andrew J. Oswald (2004), "Well-Being Over Time In Britain And The USA", Journal of Public Economics, Vol. 88:1359-1386.

Boyce, Christopher J; Gordon DA Brown; Simon C. Moore (2010), "Money and Happiness: Rank of Income, Not Income, Affects Life Satisfaction", Psychological Science, Vol. 21 No. 4: 471-5.

Clark, Andrew E.; Frijters, Paul; Shields, Michael A (2006), "Income and Happiness: Evidence, Explanations and Economic Implications", Working Paper.

Clark, Andrew E.; Frijters, Paul; Shields, Michael A (2008) "Relative İncome, Happiness, And Utility: An Explanation For The Easterlin Paradox And Other Puzzles", Journal of Economic Literature, Vol.46 No.1: 95-144.

Dittmann, Joerg; Goebel, Jan (2010), "Your House, Your Car, Your Educatio: The Socioeconomic Situation of the Neighborhood and its Impact on Life Satisfaction in Germany", Social Indıcators Research, Vol.96 No.3:497-513.

Easterlin, Richard A. (1974), "Does Economic Growth Improve The Human Lot? Some Empirical Evidence", Nations and Households in Economic Growth, Vol.89: 89-125.

Easterlin, Richard. A. (2005), "Diminishing Marginal Utility Of İncome? Caveat Emptor", Social Indicators Research, Vol.70 No.3: 243-255.

Erim, Neşe (2011), İktisadi Düşünce Tarihi, Kocaeli: Umuttepe Yayınları.

Erlinghagen, Marcel (2012), "Nowhere Better Than Here? The Subjective Well-Being Of German Emigrants And Remigrants", Comparative Population Studies, Vol. 36 No. 4: 911-920.

Gemlik, Nilay; Sığrı, Ünsal; Sur, Haydar (2007), "Sosyal Karşılaştırma ve Öğrenilmiş Güçlülük İlişkisinin Yönetsel Etkileri Hastane Yöneticileri ve Çalışanları Üzerine Bir Çalışma", Yönetim İstanbul Üniversitesi İşletme Fakültesi Iktisadı Enstitüsü Dergisi, C.17 No.57: 55-66.

Güler, Abdurrahim; Tacoğlu Poyraz, Tuğça (2017), “Amerika’da Yaşayan Türklerde Etnik Kimlik, Kültürleşme, Dindarlık ve Bunların Yaşam Memnuniyetine Etkisi”, Akademik Bakış Dergisi, No.63:59-70.

Gökdemir Dumludağ, Özge (2011), "Mutluluk ve İktisadi Parametreler Üzerine Bir İnceleme", Yayınlanmamış Doktora Tezi, İstanbul Üniversitesi SBE.

Helliwel, John F. (2003), "How's life? Combining Individual and National Variables to Explain Subjective Well-Being", Economic Modelling, Vol.20 No.2: 331-360.

Hendriks, Martijn (2015), "The Happiness of International Migrants: A Review of Research Findings", Migration Studies, Vol.3, No.3: 343-369.

Knight, John; Gunatilaka, Ramani (2010), "Great Expectations? The Subjective Well-Being of Rural-Urban Migrants in China", World Development, Vol.38 No.1: 113-124.

Lelkes, Orsolya (2006), "Knowing What is Good For You: Empirical Analysis of Personal Preferences and The "Objective Good", The Journal of Socio-Economics, Vol.35 No.2: 285-307.

Lucas, Richard E. (2005), "Time does not heal all wounds: A longitudinal study of reaction and adaptation to divorce", Psychological science, Vol.16 No.12: 945-950.

Luhmann, Maike, Michael Eid (2009) "Does it Really Feel The Same? Changes in Life Satisfaction Following Repeated Life Events", Journal of Personality and Social Psychology, Vol.97 No.2: 363-381. 
Luhmann, Maike; Wilhelm, Hofmann; Michael, Eid; Richard E., Lucas (2012), "Subjective Well-Being And Adaptation To Life Events: A Meta-Analysis", Journal Of Personality And Social Psychology, Vol.102 No.3: 592.

Lykken, David; Auke Tellegen (1996), "Happiness is a Stochastic Phenomenon", Psychological Science, Vol.7, No.3, 186189.

Mahonen, Tuuli Anna; Leinonen, Elina; Jasinskaja-Lahti Inga (2013), “Met Expectations and the Wellbeing of Diaspora Immigrants: A Longitudinal Study", International Journal of Psychology, Vol.48 No.3: 324-33.

Melzer, Silvia Maja (2011),"Does Migration Make You Happy? The İnfluence Of Migration On Subjective Wellbeing", Journal of Social Research and Policy, Vol.2 No.2: 73-92.

Melzer, Silvia; Ruud Muffels (2012), "Migrant's Pursuit of Happiness-The Impact of Adaptation, Social Comparison and Relative Deprivation: Evidence from a 'Natural'Experiment", German Socio-Economic Panel Study (SOEP), 2-9.

Polgreen, Linnea; Nicole B. Simpson (2011), "Happiness and International Migration", Journal of Happiness Studies, Vol.12 No.5: 819-840.

Ratha, Dilip; William Shaw (2007), "South-South Migration and Remittances", Washington, DC: World Bank Development Prospects Group, Working Paper.

Safi, Mirna (2006), "Immigrants' Life Satisfaction In Europe: Between Assimilation And Discrimination", European Sociological Review, Vol.26 No. 2: 159-176.

Schündeln, Matthias; Nicola, Fuchs-Schündeln (2009), "Who Stays, Who Goes, Who Returns? East-West Migration Within Germany Since Reunification", Economics of Transition, Vol.17 No.3: 703-738.

Senik, Claudia (2009), "Direct Evidence On Income Comparisons And Their Welfare Effects", Journal of Economic Behavior and Organization, Vol.72 No.1: 408-424.

Senik, Claudia (2014), "The French Unhappiness Puzzle: The Cultural Dimension of Happiness, Journal of Economic Behavior \& Organization_Vol.106: 379-401

Simpson, Nicole B. (2012), "Happiness and Migration", International Handbook on The Economics of Migration, (Ed. Klaus F. Zimmermann and Amelie F. Constant), USA: Edward Elgar Publishing Limited, 10-18.

Stillman, Steven; Gibson, John; McKenzie, David; Rohorua, Halahingano (2015), "Miserable Migrants? Natural Experiment Evidence on International Migration and Objective and Subjective Well-Being'", World Development, No.65: 79-93.

Ullman, Chana; Moshe Tatar (2001), 'Psychological Adjustment among Israeli Adolescent Immigrants: A Report on Life Satisfaction, Self-Concept, and Self-Esteem', Journal of Youth and Adolescence, Vol.30 No.4: 449-463.

Voicu, Bogdan; Vasile, Marian (2014), “Do “Cultures of Life Satisfaction” Travel?”, Current Sociology, Vol.62 No.1: 8199. 
Neoclassical economics, the dominant understanding of economics today, defines individuals as selfish, whole and who have cost-free knowledge and act to maximize their benefits. Theory does not consider the individual as a social entity, it also distinguishes the individual from the society in which he was born and raised and the concepts such as value judgment, union, religious community, political views that constitute that society, and socio-demographic characteristics such as gender, belief, age, and marital status that he or she acquired later. The neoclassic theory, founded on this rationale individual, suggests that the satisfaction of the society can be measured through objective financial parameters. This isolate the human being from psychological, sociological and cultural factors, does not include psychology in its models, which is a scientific discipline, and detracts from value judgement of economics and subjectivity.

The rational individual of mainstream economics has begun to be criticized intensely over time. The use of only objective economic parameters has been criticized particularly in the field of life satisfaction, and the concept of "happiness", which includes the social, cultural and emotional aspects of the individual and includes psychological factors, has been used instead of the concept of benefit. This concept, which was previously the subject of sociology, medicine and psychology, started to take place in the field of economics under the name of "economics of happiness." Happiness studies, which have found a wide range of research fields, have been the subject of research in the field of migration since 2005 .

Except for mandatory reasons such as war, natural disaster, etc., individuals generally migrate in order to increase their well-being and to achieve better living standards. The individual whose main purpose is to increase their happiness by migration uses migration as a tool in this way. Therefore, happiness studies in the field of migration can also be seen as an indicator of whether migrants have achieved these goals. In happiness-migration researches, answers are asked to the questions under which conditions and to what extent the immigrants are happy, to which countries they tend to migrate, whether immigration to rich countries brings more happiness and whether the increase in income after immigration alone is sufficient to increase happiness. This paper, which is a literature review, is a synthesis of happiness-migration studies conducted to determine the life satisfaction of migrants.

Neoclassical Migration Theory suggests that individuals have complete information about pre- and post-migration and make a rational choice by calculating the benefit-cost when making a migration decision. In reality, individuals cannot be happy only by increasing their income when they migrate to another country. There are a large number of economic, social, cultural and psychological costs that the individual endures and cannot fully calculate during and after the migration. For example, if the factors such as the feeling of longing, feelings of discrimination and cultural differences that the individual feels after immigration exceed the level of benefit arising from the income, this can cause the individual to be unhappy. These costs, which are neglected by neoclassical economics, are not neglected in happiness studies in the field of migration.

In the studies carried out in the field of happiness-migration, it was determined that not only economic factors affect the life satisfaction of the individual but also other factors excluded by neoclassical economics. For example, according to the studies conducted in the happiness-migration literature, it was determined that many reasons such as changing reference groups through which individuals compare themselves after migration, development difference between country the individuals migrated and the country the individual left behind, or the individual's post migration adaptation process have an impact on the life satisfaction of migrants.

There are interesting results in the studies conducted in this field. For example, in Happiness-migration studies, it was revealed that individuals mostly make migration decisions with relative income anxiety. The fact that the immigrant earns lower absolute income than his / her income before immigration does not mean that the individual will be unhappy. For example, if the individual has a higher socio-economic position in the country of destination than the country he left behind, this may cause the individual to be happier even if he / she earns lower income. Or if money is relatively important, migrating to a richer country can have a negative impact on an individual's happiness. For this reason, in some studies, it was observed that happiness of individuals decreased despite absolute income increase.

Another important factor in the happiness of individuals after migration is who is the reference group to which the individual compares himself. It has been observed that if the individual compares himself with the people he has left behind, this has a positive effect on the happiness of the individual, and if the individual refers to the people of the 
country of destination (if the individual compares himself with the people of the country of destination), this has a negative effect on the happiness of the individual.

Happiness studies in areas such as sociology and psychology indicate that the adaptation of the individual, which means adaptation to new situations, also has an effect on life satisfaction. Adaptation theory tells us that adapting to a new situation will return to its former state even if it increases the life satisfaction of individuals in the first place. Adaptation theory is referred as a reason for the decrease of life satisfaction of individuals after migration.

As a result, contrary to mainstream economics, which claims that individuals can increase their objective wellbeing only by means of income after migration, happiness-migration studies show that many sociological, cultural and psychological factors other than income affect the individual's decision to migrate and life satisfaction after migration. Absolute income growth is not the only motivation for the desire for a better life, which is the main goal of immigration. All the factors that the individual experiences during the migration process and afterwards affect the life satisfaction of the individual. 
Eskişehir Osmangazi Üniversitesi iiBF Dergisi 